
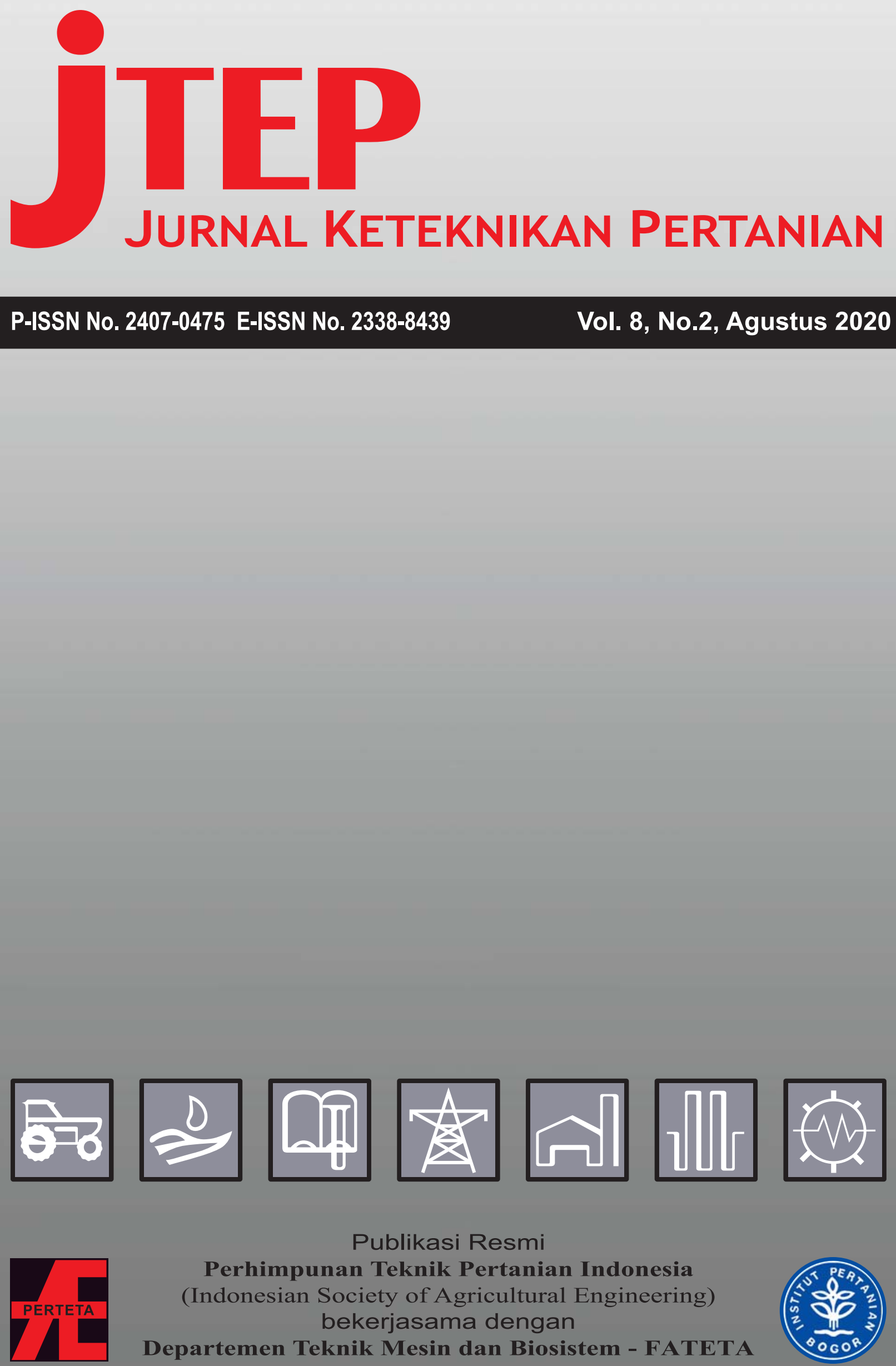

\footnotetext{
Publikasi Resmi

Perhimpunan Teknik Pertanian Indonesia (Indonesian Society of Agricultural Engineering) bekerjasama dengan

Departemen Teknik Mesin dan Biosistem - FATETA Institut Pertanian Bogor
} 


\section{jTEP JURnal Keteknikan Pertanian}

Vol. 8, No. 2, Agustus 2020

Jurnal Keteknikan Pertanian (JTEP) terakreditasi berdasarkan SK Dirjen Penguatan Riset dan Pengembangan Kementerian Ristek Dikti Nomor I/E/KPT/2015 tanggal 21 September 2015. Selain itu, JTEP juga telah terdaftar pada Crossref dan telah memiliki Digital Object Identifier (DOI) dan telah terindeks pada ISJD, IPI, Google Scholar dan DOAJ. JTEP terbit tiga kali setahun yaitu bulan April, Agustus dan Desember, Jurnal berkala ilmiah ini berkiprah dalam pengembangan ilmu keteknikan untuk pertanian tropika dan lingkungan hayati. Penulis makalah tidak dibatasi pada anggota PERTETA tetapi terbuka bagi masyarakat umum. Lingkup makalah, antara lain meliputi teknik sumberdaya lahan dan air, alat dan mesin budidaya pertanian, lingkungan dan bangunan pertanian, energi alternatif dan elektrifikasi, ergonomika dan elektronika pertanian, teknik pengolahan pangan dan hasil pertanian, manajemen dan sistem informasi pertanian. Makalah dikelompokkan dalam invited paper yang menyajikan isu aktual nasional dan internasional, review perkembangan penelitian, atau penerapan ilmu dan teknologi, technical paper hasil penelitian, penerapan, atau diseminasi, serta research methodology berkaitan pengembangan modul, metode, prosedur, program aplikasi, dan lain sebagainya. Penulisan naskah harus mengikuti panduan penulisan seperti tercantum pada website dan naskah dikirim secara elektronik (online submission) melalui http://journal.ipb.ac.id/index.php/jtep.

\section{Penanggungjawab:}

Ketua Departemen Teknik Mesin dan Biosistem, Fakultas Teknologi Pertanian,IPB

Ketua Perhimpunan Teknik Pertanian Indonesia

\section{Dewan Redaksi:}

Ketua : Yohanes Aris Purwanto (Scopus ID: 6506369700, IPB University)

Anggota : Abdul Hamid Adom (Scopus ID: 6506600412, University Malaysia Perlis)

(editorial Addy Wahyudie (Scopus ID: 35306119500, United Arab Emirates University)

board) Budi Indra Setiawan (Scopus ID: 55574122266, IPB University)

Balasuriya M.S. Jinendra (Scopus ID: 30467710700 , University of Ruhuna)

Bambang Purwantana (Scopus ID: 6506901423, Universitas Gadjah Mada)

Bambang Susilo (Scopus ID: 54418036400, Universitas Brawijaya)

Daniel Saputera (Scopus ID: 6507392012, Universitas Sriwjaya)

Han Shuqing (Scopus ID: 55039915600, China Agricultural University)

Hiroshi Shimizu (Scopus ID: 7404366016, Kyoto University)

I Made Anom Sutrisna Wijaya (Scopus ID: 56530783200, Universitas Udayana)

Agus Arif Munawar (Scopus ID: 56515099300, Universitas Syahkuala)

Armansyah H. Tambunan (Scopus ID: 57196349366, IPB University)

Kudang Boro Seminar (Scopus ID: 54897890200, IPB University)

M. Rahman (Scopus ID: 7404134933, Bangladesh Agricultural University)

Machmud Achmad (Scopus ID: 57191342583, Universitas Hasanuddin)

Muhammad Makky (Scopus ID: 55630259900, Universitas Andalas)

Muhammad Yulianto (Scopus ID: 54407688300, IPB University \& Waseda University)

Nanik Purwanti (Scopus ID: 23101232200, IPB University \& Teagasc Food Research Center Irlandia)

Pastor P. Garcia (Scopus ID: 57188872339 , Visayas State University)

Rosnah Shamsudin (Scopus ID: 6507783529, Universitas Putra Malaysia)

Salengke (Scopus ID: 6507093353, Universitas Hasanuddin)

Sate Sampattagul (Scopus ID: 7801640861, Chiang Mai University)

Subramaniam Sathivel (Scopus ID: 6602242315, Louisiana State University)

Shinichiro Kuroki (Scopus ID: 57052393500, Kobe University)

Siswoyo Soekarno (Scopus ID: 57200222075 , Universitas Jember)

Tetsuya Araki (Scopus ID: 55628028600, The University of Tokyo)

Tusan Park (Scopus ID: 57202780408, Kyungpook National University) 


\section{Redaksi Pelaksana:}

Ketua : : Usman Ahmad (Scopus ID: 55947981500, IPB University)

Sekretaris : Lenny Saulia (Scopus ID: 16744818700, IPB University)

Bendahara : Dyah Wulandani (Scopus ID: 1883926600, IPB University)

Anggota : Satyanto Krido Saptomo (Scopus ID: 6507219391, IPB University)

Slamet Widodo (Scopus ID: 22636442900, IPB University)

Liyantono (Scopus ID: 54906200300, IPB University)

Leopold Oscar Nelwan (Scopus ID: 56088768900, IPB University)

I Wayan Astika (Scopus ID: 43461110500, IPB University)

Agus Ghautsun Niam (Scopus ID: 57205687481, IPB University)

Administrasi : Khania Tria Tifani (IPB University)

Penerbit: Departemen Teknik Mesin dan Biosistem, Institut Pertanian Bogor bekerjasama dengan Perhimpunan Teknik Pertanian Indonesia (PERTETA).

Alamat: Jurnal Keteknikan Pertanian, Departemen Teknik Mesin dan Biosistem, Fakultas Teknologi Pertanian, Kampus Institut Pertanian Bogor, Bogor 16680.

Telp. 0251-8624 503, Fax 0251-8623 026,

E-mail: jtep@apps.ipb.ac.id

Website: http://journal.ipb.ac.id/index.php/jtep

Rekening: BRI, KCP-IPB, No.0595-01-003461-50-9 a/n: Jurnal Keteknikan Pertanian

Percetakan: PT. Binakerta Makmur Saputra, Jakarta 


\section{Ucapan Terima Kasih}

Redaksi Jurnal Keteknikan Pertanian mengucapkan terima kasih kepada para Mitra Bebestari yang telah menelaah naskah pada penerbitan Vol. 8, No. 2 Agustus 2020. Ucapan terima kasih disampaikan kepada: Dr. Leopold O. Nelwan, S.TP, M.Si (Departemen Teknik Mesin dan Biosistem, IPB University), Prof.Dr.Ir. Usman Ahmad, M.Agr (Departemen Teknik Mesin dan Biosistem, IPB University), Dr.Ir. Soni Solistia Wirawan, M.Eng (BPPT), Prof.Dr.Ir. Sutrisno M.Agr (Departemen Teknik Mesin dan Biosistem, IPB University), Ir. Siti Mariana Widayanti, M.Si, (Balai Besar Penelitian dan Pengembangan Pascapanen Pertanian), Dr.Ir. LilikPujantoro, M.Agr(Departemen TeknikMesin dan Biosistem, IPBUniversity). 
jiep Jurnal Keteknikan Pertanian 
Technical Paper

\title{
Pengaruh Amplitudo Ultrasonik dan Waktu Ekstraksi Terhadap Rendemen dan Mutu Oleoresin Pala
}

\author{
Effect of Ultrasound Amplitude and Extraction Time to Yield and Quality of Nutmeg \\ Oleoresin
}

\author{
I Wayan Budiastra, Department of Mechanical and Biosystem Engineering, IPB University. \\ E-mail: wbudiastra@yahoo.com \\ Sutrisno Suro Mardjan, Department of Mechanical and Biosystem Engineering, IPB University. \\ E-mail: kensutrisno@yahoo.com \\ Ahmuhardi Abdul Azis, Department of Mechanical and Biosystem Engineering, IPB University. \\ E-mail: ahmuhardi@yahoo.com
}

\begin{abstract}
Nutmeg oleoresin is one of the nutmeg derivative products with high values produced from the extraction process. The conventional extraction process using maceration takes a long time so that it is less suitable for industries needs. This study aims to examine the UAE direct sonication method for increasing yield and quality of nutmeg eleoresin. The fully matured nutmeg (six months old after flowering) were harvested, dried and milled into 60 mesh particle size. Nutmeg powder of $200 \mathrm{~g}$ was placed in beaker glass filled with etanol $800 \mathrm{ml}$ (material and solvent ratio 1:4) and UAE was carried out using a sonicator with a frequency of $20 \mathrm{kHz}$ and power of $700 \mathrm{~W}$. Four ultrasound amplitude levels $(45,60,75,90 \%)$ and four levels of extraction time (30, 45, 60, 75 minutes) were taken as UAE treatments. Extraction using maceration at room temperature for 7 hours was done as control. The results showed that the greater the amplitude of the ultrasound, the higher the yield of nutmeg oleoresin. The longer the extraction time, the higher the yield of nutmeg oleoresin. Ultrasonic assisted extraction can increase nutmeg oleoresin yield by 11 to $52 \%$ and faster time ( $\leq 1.25$ hour) than maceration extraction method ( 7 hours).
\end{abstract}

Keywords: extraction, nutmeg, oleoresin, ultrasound, yield.

\begin{abstract}
Abstrak
Oleoresin pala merupakan salah satu produk turunan pala dengan nilai tambah tinggi yang dihasilkan dari proses ekstraksi. Proses ekstraksi konvensional menggunakan metoda maserasi membutuhkan waktu yang lama sehingga kurang sesuai dengan kebutuhan industri. Penelitian ini bertujuan untuk mengkaji metoda Ultrasonic Assisted Extraction (UAE) sonikasi langsung untuk peningkatan rendemen dan mutu oleoresin pala. Buah pala tua penuh dengan umur 6 bulan setelah pembungaan dipanen, dikeringkan dan digiling menjadi ukuran partikel 60 mesh. Sebanyak $200 \mathrm{~g}$ bubuk pala ditempatkan pada wadah yang diisi etanol dengan volume $800 \mathrm{ml}$ (rasio bahan dan pelarut 1:4) dan dilakukan proses ekstraksi berbantu utrasonik menggunakan sonikator frekuensi $20 \mathrm{kHz}$ dan daya $700 \mathrm{~W}$. Ekstraksi berbantu ultrasonik dilakukan dengan perlakuan 4 tingkat amplitudo (45, 60, 75, 90\%) dan 4 tingkat waktu eksitasi $(30,45,60$, 75 menit). Ekstraksi dengan maserasi pada suhu ruang selama 7 jam digunakan sebagai kontrol. Hasil penelitian menunjukkan semakin besar amplitudo ultrasonik, maka semakin tinggi rendemen oleoresin pala. Semakin lama waktu ekstraksi, semakin tinggi pula rendemen oleoresin pala. Ekstraksi berbantu ultrasonik mampu meningkatkan rendemen oleoresin pala sebesar 11 hingga $52 \%$ dengan waktu yang lebih cepat $(\leq 1.25 \mathrm{Jam})$ dibandingkan metoda ekstraksi konvensional (7 jam).
\end{abstract}

Kata kunci: ekstraksi, oleoresin, pala, rendemen, ultrasonik. 


\section{Pendahuluan}

Indonesia kaya akan tanaman rempah antara lain pala yang mempunyai nilai ekonomi tinggi. Namun, komoditas tersebut kebanyakan masih diolah secara terbatas dalam bentuk simplisia (kering) dan bubuk/tepung untuk bahan baku industri dengan mutu yang beragam, mengandung cemaran mikroba tinggi, sehingga nilai tambahnya rendah. Hanya sebagian kecil tanaman rempah yang diolah menjadi produk setengah jadi dalam bentuk minyak atsiri, oleoresin atau ekstrak rempah tertentu dengan nilai tambah yang cukup tinggi. Oleoresin adalah minyak kental terdiri dari campuran minyak esensial dan resin dengan karakteristik flavor, aroma dan komposisi kimia serupa dengan bahan bakunya. Oleoresin digunakan oleh industri makanan, minuman, sebagai penambah cita rasa dan sebagai ramuan dalam industri obat-obatan, kosmetika, dan sabun (Assagaf et al. 2012).

Salah satu kendala yang dihadapi produsen minyak atsiri dan oleoresin dalam negeri adalah kualitas dan harga yang tidak dapat bersaing salah satunya karena masih menggunakan teknologi ekstraksi konvensional (maserasi). Teknologi maserasi umumnya berjalan lambat dan menghasilkan rendemen dan kualitas yang rendah. Diperlukan metode ekstraksi yang lebih cepat salah satunya dengan ekstraksi berbantu ultrasonik (ultrasonic assisted extraction (UAE)). UAE sudah dikenal luas dan efektif dalam meningkatkan efektifitas dan efisiensi proses ektraksi. Namun kebanyakan teknologi UAE yang digunakan adalah teknologi sonikasi tidak langsung (menggunakan water bath) (Supardan et al. 2011) Penerapan teknologi sonikasi langsung dimana transduser ultrasonik kontak langsung dengan pelarut dan bahan yang diekstrak untuk ekstraksi rempah Indonesia masih terbatas.

Balachandran et al. (2006) melakukan ekstraksi berbantu ultrasonik pada jahe yang dapat meningkatkan $30 \%$ rendemen dan mengurangi waktu ekstraksi. Xia et al. (2006) membuktikan bahwa ekstraksi berbantu ultrasonik pada polifenol, asam amino dan kafein dari teh hijau dapat meningkatkan rendemen pada suhu $65^{\circ} \mathrm{C}$. Pada percobaan yang lain, Vinatoru et al. (1997) melakukan studi kelayakan ultrasonik untuk ekstraksi senyawa bioaktif dari bahan tanaman yang menghasilkan bahan obat-obatan, Golmohamadi et al. (2013) untuk puree raspberi merah, dan Gonzales et al. (2015) untuk buah anggur. Sholihah et al. (2017) melakukan ekstraksi kulit manggis menggunakan UAE dengan perlakuan amplitudo $(35,50,65 \%)$ dan waktu ekstraksi $(15,30$ dan 45 menit), menyimpulkan amplitudo $65 \%$ dan waktu ekstraksi 45 menit menghasilkan rendemen antosianin dan aktivitas antioksidan tertinggi. Baihaqi et al. (2018) melakukan pengkajian UAE pada dua tingkat amplitudo (20\% dan $40 \%$ ) dan tiga ukuran partikel (20, 40, 60 mesh), menyimpulkan bahwa amplitudo $40 \%$ dan ukuran partikel 60 mesh menghasilkan rendemen oleoresin pala Bogor tertinggi. Namun produk oleoresin yang dihasilkan masih belum memenuhi standar mutu industri sehingga memerlukan penelitian lebih lanjut. Aplikasi UAE untuk ekstraksi total polifenol dan kafein dari biji kopi dilakukan Ahmad et al. (2018), Aryanti et al. 2018 untuk ekstraksi rosella, Uju et al. (2019) untuk ekstraksi rumput laut, dan Yang et al. (2019) untuk ekstraksi Anoectochilus roxburghii. Hasil penelitian tersebut menyimpulkan bahwa UAE mampu meningkatkan rendemen dan menghemat waktu ekstraksi dibandingkan maserasi. Tujuan penelitian ini adalah mengkaji metoda UAE sonikasi langsung untuk peningkatan rendemen dan mutu oleoresin pala.

\section{Bahan dan Metode}

\section{Bahan dan Alat}

Bahan yang digunakan adalah buah pala tua dengan umur petik 6 bulan (sejak pembungaan dari umur pohon 60 tahun), diperoleh dari kebun petani di desa Tanah Rata, Banda, Maluku Tengah. Buah pala dengan umur petik 6 bulan digunakan karena ketersediaan bahan baku yang ada, meski kurang optimal dalam menghasilkan minyak pala dibandingkan umur petik 9-12 bulan. Bahan lain yang digunakan adalah kertas saring dan etanol $96 \%$. Selain itu juga digunakan air dan es batu sebagai media pendingin. Alat yang digunakan adalah perangkat UAE yaitu Sonikator (QSonica model Q700 buatan USA), frekuensi $20 \mathrm{kHz}$ dan daya 700 Watt probe berdiameter 1" tipe replaceable tip part 4210 . Pengontrol suhu ekstraksi terdiri dari mikrokontroler, sensor suhu, water bath, ice box dan pompa. Alat lainnya adalah pisau, timbangan analitik mettle PM, cabinet dryer, termokopel, hammer mill, ayakan Tyller, gelas beker $1 \mathrm{~L}$, pengaduk, botol vial $30 \mathrm{ml}$, corong, dan rotary vacuum evaporator. Peralatan yang digunakan untuk analisis sifat fisiko kimia oleoresin adalah chromameter untuk pengukuran warna, piknometer untuk bobot jenis, oven untuk kadar air, dan GCMS (Gas Chromatography Mass Spectrometer) untuk penentuan komponen penyusun oleoresin.

\section{Metode}

Buah pala diproses menjadi biji pala mutu 1 (SNI 0006:2015) mengikuti Technical Guidelines of Postharvest Handling of Nutmeg in Indonesia by Ministry of Agriculture. Biji pala dengan kadar air awal $70 \%$ dikeringkan dengan penjemuran selama 7 hari untuk mencapai kadar air $7-10 \%$. Kemudian biji dipisahkan dengan cangkangnya, dan selanjutnya biji pala digiling dengan hammer mill, kemudian diayak menggunakan saringan 60 mesh. Sebanyak $200 \mathrm{~g}$ bubuk giling pala ditempatkan 
Tabel 1. Kadar air dan lemak serbuk biji pala.

\begin{tabular}{ccc}
\hline Ulangan & Kadar air $(\%)$ & Kadar Lemak $(\%)$ \\
\hline 1 & 7.12 & 31.00 \\
2 & 7.20 & 31.01 \\
3 & 7.13 & 30.97 \\
Rerata & 7.15 & 30.99 \\
\hline
\end{tabular}

Tabel 2. Rendemen oleoresin pala pada berbagai ampitudo dan waktu ekstraksi.

\begin{tabular}{cccccc}
\hline \multirow{2}{*}{$\begin{array}{c}\text { Maserasi } \\
\text { (kontrol) }\end{array}$} & $\begin{array}{c}\text { Waktu } \\
\text { (menit) }\end{array}$ & 45 & 60 & 75 & 90 \\
\cline { 3 - 6 } & 30 & $12.04 \pm 0.25^{4 \mathbf{d}}$ & $12.79 \pm 0.35^{3 \mathbf{d}}$ & $13.65 \pm 0.37^{\mathbf{2 d}}$ & $14.36 \pm 0.29^{1 \mathbf{d}}$ \\
& 45 & $12.70 \pm 0.17^{4 \mathbf{c}}$ & $13.66 \pm 0.34^{\mathbf{c}}$ & $14.10 \pm 0.21^{\mathbf{2 c}}$ & $15.10 \pm 0.13^{1 \mathbf{c}}$ \\
$10.80 \pm 0.05^{\mathrm{e}}$ & 60 & $13.74 \pm 0.14^{4 \mathbf{b}}$ & $14.32 \pm 0.40^{3 \mathbf{b}}$ & $15.32 \pm 0.01^{\mathbf{2 b}}$ & $15.69 \pm 0.01^{1 \mathbf{b}}$ \\
& 75 & $14.19 \pm 0.17^{4 \mathbf{a}}$ & $15.21 \pm 0.14^{3 \mathbf{a}}$ & $15.76 \pm 0.12^{\mathbf{2 a}}$ & $16.38 \pm 0.12^{1 \mathbf{a}}$ \\
\hline
\end{tabular}

pada wadah (gelas beker) yang diisi etanol dengan volume $800 \mathrm{ml}$ (rasio bahan dan pelarut 1:4) dan dilakukan proses ekstraksi berbantu utrasonik. Ekstraksi dengan maserasi pada suhu ruang selama 7 jam digunakan sebagai kontrol (Sofyana et al. 2013). Ekstraksi berbantu ultrasonik dilakukan dengan perlakuan 4 amplitudo yaitu 45\% (A45), $60 \%$ (A60), 75\% (A75), dan 90\% (A90) dan 4 waktu ekstraksi yaitu 30 menit (B30), 45 menit (B45), 60 menit (B60), dan 75 menit (B75). Dengan demikian ada 16 perlakuan UAE. Setelah proses ekstraksi selesai, dilakukan penyaringan dan pemekatan menggunakan rotary vacuum evaporator pada tekanan $20 \mathrm{KPa}$ dan suhu $50^{\circ} \mathrm{C}$. Oleoresin yang dihasilkan dihitung rendemen, diukur kandungan air dengan metode gravimeteri (AOAC 1995), lemak dengan metoda sohklet (AOAC 1995), komponen penyusun menggunakan GCMS (AOAC 1995), bobot jenis dengan piknometer dan warna dengan chromameter. Rancangan percobaan yang digunakan adalah rancangan acak lengkap faktorial dengan dua faktor (amplitudo dan waktu eksitasi) masing masing terdiri dari 4 perlakuan. Amplitudo adalah jarak yang dilalui ujung probe yang outputnya dapat diatur dari 1-100\%. Amplitudo yang diukur pada output $100 \%$ dari probe yang digunakan adalah $30 \mu \mathrm{m}$. Setiap kombinasi perlakuan diulang sebanyak 2 kali sehingga terdapat 32 unit percobaan. Analisis varian rancangan percobaan dilakukan untuk mengetahui perbedaan perlakuan ultrasonik terhadap kontrol, pengaruh 2 faktor terhadap parameter uji dan interaksi diantara kedua faktor. Untuk uji lanjut dilakukan dengan uji Duncan's Multiple Range Test (DMRT) pada taraf nyata $95 \%$ atau pada p-value 0.05 .

\section{Hasil dan Pembahasan}

Kadar air serbuk pala untuk bahan ekstraksi berkisar 7.12 hingga $7.20 \%$ (Tabel 1). Tingkat kadar air ini memenuhi persyaratan untuk proses ekstraksi $(<10 \%)$. Sedangkan kadar lemak serbuk pala cukup tinggi berkisar 30.97 hingga 31.01\%, masih dalam rentang kadar lemak biji pala tua (fully matured) yang berkisar antara 30-35\%, lebih tinggi dari biji pala muda yang berkisar $26-28 \%$. Pada biji pala muda, kandungan minyak atsiri tinggi sebagai hasil metabolisme tanaman pala, sedangkan pada biji pala tua kandungan minyak atsiri rendah yang pembentukannya terhenti karena sebagian sudah diikat oleh lemak (Baihaqi et al. 2017). Kadar lemak memegang peranan penting dalam penentuan rendemen oleoresin pala. Semakin tinggi kadar lemak, semakin tinggi rendemen oleoresin pala.

Dengan bahan baku yang sama (biji pala kualitas grade 1 dan pengeringan dengan penjemuran selama 7 hari hingga kadar air $7 \%$ ), serta rasio bahan dan pelarut (1:4) dan ukuran partikel (60 mesh) yang sama, rendemen yang dihasilkan dengan metode UAE adalah 12.04\%-16.38\%, berbeda nyata dengan maserasi $(10.80 \%)$. Metode UAE menghasilkan rendemen oleoresin yang lebih tinggi (11 hingga 52\%) dibandingkan metode konvensional (maserasi) (Tabel 2). Hasil ini sesuai dengan penelitian Baihaqi et al. 2018, Sholihah et al. 2017, dan Audah et al. 2018 yang menyebutkan bahwa UAE menghasilkan rendemen lebih tinggi dari maserasi. Peningkatan rendemen oleoresin oleh UAE disebabkan karena UAE menghasilkan energi kavitasi dan membentuk gelembung pada pelarut yang mampu memecah dinding sel serbuk pala, sehingga meningkatkan difusi pelarut ke serbuk pala dan laju pindah massa. Amplitudo dan waktu ekstraksi serta interaksinya berpengaruh nyata terhadap rendemen. Semakin besar amplitudo ultrasonik, semakin tinggi rendemen oleoresin pala. Hasil ini konsisten dengan hasil riset Gonzales et al. 2015 dan Baihaqi et al. 2018 dimana amplitudo tertinggi menghasilkan rendemen oleoresin pala tertinggi. Meningkatnya amplitudo akan meningkatkan energi kavitasi, difusi pelarut 
Tabel 3. Jumlah Konsumsi Energi Aktual Ultrasonikasi (kJ).

\begin{tabular}{crrrc}
\hline \multirow{2}{*}{ Waktu (menit) } & \multicolumn{4}{c}{ Amplitudo (\%) } \\
\cline { 2 - 5 } & \multicolumn{1}{c}{45} & 60 & 75 & 90 \\
\hline 30 & 44.32 & 58.15 & 74.66 & 102.04 \\
45 & 84.22 & 88.05 & 126.66 & 161.55 \\
60 & 102.89 & 147.54 & 191.85 & 236.27 \\
75 & 138.79 & 175.45 & 234.12 & 308.88 \\
\hline
\end{tabular}

Tabel 4. Bobot jenis oleoresin pala pada berbagai tingkat amplitudo dan waktu ekstraksi.

\begin{tabular}{cccccc}
\hline \multirow{2}{*}{ Maserasi } & Waktu & \multicolumn{4}{c}{ Amplitudo (\%) } \\
\cline { 2 - 6 } & (menit) & 45 & 60 & 75 & 90 \\
\hline \multirow{3}{*}{$1.0214^{\mathrm{a}}$} & 30 & $1.0160^{1 \mathrm{a}}$ & $1.0403^{\mathrm{la}}$ & $1.0338^{\mathrm{aa}}$ & $1.0494^{1 \mathrm{a}}$ \\
& 45 & $1.0357^{1 \mathrm{a}}$ & $1.0211^{\mathrm{a}}$ & $1.0395^{\mathrm{aa}}$ & $1.0518^{1 \mathrm{a}}$ \\
& 60 & $1.0280^{1 \mathrm{a}}$ & $1.0357^{\mathrm{aa}}$ & $1.0435^{\mathrm{aa}}$ & $1.0203^{1 \mathrm{a}}$ \\
& 75 & $1.0204^{1 \mathrm{a}}$ & $1.0075^{\mathrm{aa}}$ & $1.0346^{\mathrm{aa}}$ & $1.0174^{1 \mathrm{a}}$ \\
\hline
\end{tabular}

Tabel 5. Warna oleoresin pala pada berbagai perlakuan UAE dan kontrol.

\begin{tabular}{ccccccc}
\hline Kode Sampel & L & A & B & Ch & Hue $\left(^{\circ}\right)$ & Warna \\
\hline A30B45 & 20.47 & 1.17 & 0.95 & 1.51 & 41.85 & Merah \\
A30B60 & 20.54 & 2.40 & 2.21 & 3.26 & 44.46 & Merah \\
A30B75 & 19.77 & 1.14 & 1.00 & 1.57 & 51.55 & Merah \\
A30B90 & 20.30 & 1.20 & 1.21 & 1.71 & 44.94 & Merah \\
A45B45 & 20.53 & 0.96 & 0.76 & 1.23 & 40.70 & Merah \\
A45B60 & 20.29 & 1.84 & 1.69 & 2.50 & 41.62 & Merah \\
A45B75 & 19.11 & 1.90 & 2.01 & 2.81 & 58.92 & Merah kekuningan \\
A45B90 & 19.59 & 1.13 & 1.12 & 1.59 & 47.10 & Merah \\
A60B45 & 19.80 & 1.25 & 1.24 & 1.78 & 51.17 & Merah \\
A60B60 & 21.19 & 0.56 & 0.64 & 0.87 & 51.25 & Merah \\
A60B75 & 20.19 & 0.66 & 0.92 & 1.15 & 59.17 & Merah kekuningan \\
A60B90 & 20.30 & 1.18 & 1.24 & 1.73 & 50.41 & Merah \\
A75B45 & 19.99 & 0.50 & 0.72 & 0.90 & 60.65 & Merah kekuningan \\
A75B60 & 16.76 & 0.43 & 0.78 & 0.90 & 59.78 & Merah kekuningan \\
A75B75 & 18.88 & 0.55 & 0.78 & 0.97 & 57.31 & Merah kekuningan \\
A75B90 & 18.95 & 1.61 & 1.31 & 2.11 & 48.98 & Merah \\
Kontrol & 18.30 & 0.14 & 0.68 & 0.70 & 78.44 & Merah kekuningan \\
\hline
\end{tabular}

ke bahan dan laju pindah massa yang berpengaruh terhadap peningkatan rendemen oleoresin pala. Semakin lama waktu ekstraksi, semakin tinggi pula rendemen oleoresin pala. Meskipun amplitudo 90\% dan waktu ekstraksi 75 menit menghasilkan rendemen yang paling tinggi, perlakuan UAE tersebut belum dapat dikatakan yang paling optimal dan efisien untuk produksi oleoresin pala. Perlu analisis lebih lanjut khususnya menyangkut volume produksi dan biaya ekstraksi masing masing perlakuan untuk menentukan perlakuan UAE yang optimal dan efisien.

Meskipun rendemen meningkat karena peningkatan amplitudo dan waktu ekstraksi, peningkatan amplitudo dan waktu ekstraksi menyebabkan penggunaan energi aktual yang lebih banyak (Tabel 3) dan dapat berimplikasi pada peningkatan biaya ekstraksi. Konsumsi energi akibat peningkatan waktu ekstraksi (1.5 hingga 3 kali) lebih besar dibandingkan akibat peningkatan amplitudo ultrasonik (1.05 hingga 2.23 kali). Hal ini memberikan indikasi bahwa biaya ekstraksi akan menjadi lebih efisien pada waktu ekstraksi yang lebih singkat.

Metoda UAE menghasilkan oleoresin dengan bobot jenis yang sama dengan metoda maserasi (Tabel 4). Bobot jenis antar perlakuan UAE tidak berbeda nyata. Bobot jenis baik yang dihasilkan dari metoda UAE maupun maserasi sedikit lebih tinggi dari standar oleoresin pala (FAO) yang berkisar 0.88 sampai 0.91 . Hal ini dapat disebabkan oleh mutu bahan baku, proses pascapanen dan proses ekstraksi. 
Tabel 6. Komponen penyusun oleoresin pala pada beberapa perlakuan UAE dan kontrol.

\begin{tabular}{lccccc}
\hline Komponen Penyusun & \multicolumn{4}{c}{ Konsentrasi (\%) } & Kontrol \\
\cline { 2 - 5 } & A30B45 & A45B60 & A60B75 & A75B90 & \\
\hline Asam miristat & 25.83 & 22.39 & 23.44 & 26.97 & 27.25 \\
N-4 methylphenol 2 Hydroxymino acetamide & 16.19 & 16.20 & 19.02 & 12.77 & 21.16 \\
Myristicin & 10.11 & 11.93 & 11.26 & 11.39 & 12.46 \\
Licarin A & 8.89 & 8.11 & 8.6 & 7.66 & 9.81 \\
Total komponen utama & 61.02 & 58.63 & 62.32 & 58.79 & 70.68 \\
Jumlah komponen & 53 & 49 & 54 & 51 & 31 \\
\hline
\end{tabular}


.Gambar 1. Peningkatan suhu pada proses ekstraksi berbantu ultrasonik 
Warna oleoresin yang dihasilkan oleh ekstraksi dengan UAE adalah merah atau merah kekuningan (Tabel 5). Beberapa kombinasi perlakuan ekstraksi UAE menghasilkan warna oleoresin yang sama (merah kekuningan) dengan oleroresin hasil proses ekstraksi maserasi yaitu A45B75, A60B75, A75B45, A75B60, dan A75B75. Perlakuan UAE A75B90 dengan rendemen oleoresin tertinggi menghasilkan warna merah yang berbeda dengan maserasi (merah kekuningan). Hal ini mengindikasikan bahwa perlakuan dengan rendemen tinggi tidak selalu menghasilkan mutu oleoresin (warna) yang tinggi.

Analisis GC-MS terhadap oleoresin pala diperoleh jenis dan jumlah komponen yang berbeda antar perlakuan UAE (Tabel 6). Ekstraksi berbantu ultrasonik menghasilkan jenis komponen penyusun yang lebih banyak (49 hingga 54 komponen) dibandingkan kontrol/maserasi (31 komponen). Komponen kimia terbanyak pada oleoresin pala $(>7 \%)$ adalah asam miristat, N-4 methylphenol 2 Hydroxymino acetamide, Myristicin, dan Licarin A. Jumlah keempat komponen ini pada oleoresin pala hasil UAE (58.63 hingga 62.31\%) lebih rendah dibandingkan dengan kontrol (70.68\%). Hal ini menunjukkan bahwa UAE mampu mengekstrak komponen penyusun yang lebih murni dan banyak dibandingkan maserasi. Rodianawati (2010) \& Nowak et al. (2015) menyebutkan Myristicin merupakan komponen penyusun utama dari oloeresin pala sehingga menjadi indikator penentuan kualitas dari oleoresin pala. Rahman et al. (2015) mengatakan mutu minyak pala salah satunya ditentukan oleh kandungan Myristicin yang memberikan aroma khas pada oleoresin pala. Myristicin merupakan turunan dari senyawa fenilpropanoid, berupa zat cair bening, tak larut air tetapi larut dalam pelarut organik. Baunya khas seperti rempah-rempah dan aromanya tajam serta mudah menguap dan mempunyai berat molekul $192 \mathrm{gram} / \mathrm{mol}$ (Baihaqi 2017).

Peningkatan suhu terjadi pada proses ektraksi menggunakan ultrasonik (Gambar 1). Hal ini sesuai teori dan mekanisme ekstraksi berbasis ultrasonik. Gelombang ultrasonik membuat gelembung kavitasi (cavitation bubbles) pada material larutan. Ketika gelembung pecah dekat dengan dinding sel maka akan terbentukgelombang kejut dan pancaran cairan (liquid jets) yang akan membuat dinding sel pecah. Pecahnya dinding sel akan membuat komponen di dalam sel keluar bercampur dengan larutan. Pembangkitan ultrasonik secara lokal dari kavitasi mikro pada sekeliling bahan yang akan diekstraksi juga menyebabkan terjadi pemanasan pada bahan tersebut dan akan melepaskan senyawa ekstrak. Semakin lama eksitasi gelombang ultrasonik, maka suhu pada proses ekstraksi semakin meningkat. Pada amplitudo 75 dan 90\%, laju peningkatan suhu semakin besar. Namun peningkatan suhu yang terlalu tinggi dapat berakibat pada menurunnya mutu oleoresin yang dihasilkan, khususnya mutu warna. Karena itu dalam penelitian ini suhu ekstraksi dikendalikan maksimum $40^{\circ} \mathrm{C}$.

\section{Simpulan}

1. Ekstraksi berbantu ultrasonik mampu meningkatkan rendemen oleoresin pala sebesar 11 hingga $52 \%$ dan waktu yang lebih cepat ( $\leq 1.25$ jam) dibandingkan metoda maserasi $(7$ jam).

2. Ekstraksi berbantu ultrasonik menghasilkan mutu kimia oleoresin (antara lain myristicin) yang lebih murni dibandingkan metoda maserasi, tetapi menghasilkan mutu fisik (bobot jenis dan warna) yang sama dengan metoda maserasi.

\section{Ucapan Terima kasih}

Ucapan terima kasih disampaikan kepada Direktorat Penelitian dan Pengabdian Masyarakat, Kemenristekdikti atas pendanaan melalui Program Penelitian Strategis Nasional (PSN) dengan Nomor Kontrak Perjanjian: 129/SP2H/PTNBH/ DRPM/2018.

\section{Daftar Pustaka}

[AOAC] Association of Official Analytical Chemists. 1995. Official Methods of Analysis, $16^{\text {th }}$ ed. 45:56. Washington DC (US).

Aryanti, N., A. Nafiunisa, and D.H. Wardhani. 2019. Conventional and Ultrasound-Assisted Extraction of Anthocyanin from Red and Purple Roselle (Hibiscus sabdariffa L.) Calyces and Characterisation of Its Anthocyanin Powder. International Food Research Journal 26(2): 529535.

Assagaf, M., P. Hastuti, C. Hidayat, Supriyadi. 2012. Optimasi Ekstraksi Oleoresin Pala (Myristica fragrans Houtt) Asal Maluku Utara Menggunakan Response Surface Methodology (RSM). Agritech: 32(4):383-391.

Baihaqi, 2017. Peningkatan Efektivitas Ekstraksi Oleoresin Pala (Myristica Fragrans) Menggunakan Metode Berbantu Ultrasonik. (Thesis). Institut Pertanian Bogor. Bogor.

Baihaqi, I.W. Budiastra, S. Yasni, E. Darmawati. 2018. Peningkatan Efektivitas Ekstraksi Oleoresin Pala Menggunakan Metode Ultrasonik. Jurnal Keteknikan Pertanian. 6(3): 249-254.

Balachandran, S., S.E. Kentish, R. Mawson, M. Ashokkumar. 2006. Ultrasonic Enhancement of The Supercritical Extraction from Ginger. Ultrason Sonochem. 13(6):471-479.

Yang, B., M. Zhang, H. Weng, Y. Xu and L. Zeng. 2019. Optimization of Ultrasound Assisted 
Extraction (UAE) of Kinsenoside Compound from Anoectochilus roxburghii (Wall.) Lindl by Response Surface Methodology (RSM). Molecules 2020, 25, 193.

Golmohamadi, G., G. Moller, J. Powers, C. Nindo. 2013. Effect of Ultrasonic Frequency on Antioxidant Activity, Total Phenolic and Anthocyanin Content of Red Raspberry Puree. Ultrason Sonochem.20:1316-1323.

Gonzalez-Centeno, M.R., F. Comas-Serra, A. Femenia, C. Rosello, S. Simal. 2015. Effect of Power Ultrasonic Application on Aqueous Extraction of Phenolic Compounds and Antioxidant Capacity from Grape Pomace (Vitis Vinifera L.): Experimental Kinetics and Modeling. UltrasonSonochem. 22: 506-514

Ahmad, I., A.S. Pertiwi, Y.H. Kembaren, A. Rahman, A. Mun'im. 2018. Application of Natural Deep Eutectic Solvent-Based Ultrasonic Assisted Extraction of Total Polyphenolic and Caffeine Content from Coffee Beans (Coffea Beans L.) For Instant Food Products . Journal of Applied Pharmaceutical Science Vol. 8(08), pp 138-143.

Sholihah, M., U. Ahmad, I.W. Budiastra. 2017. Aplikasi Gelombang Ultrasonik untuk Meningkatkan Rendemen Ekstraksi dan Efektivitas Antioksidan Kulit Manggis. Jurnal Keteknikan Pertanian. 5(2) : 161-168

Nowak, J., W. Michał, G. Marta, S. Anna, P. Kościelniakl. 2015. Development of Advance Extraction Methods for the Extraction of Myristicin from Myristica fragrans. Food Anal. Methods. 9(5):1246-1253.
Rahman, N.A.A., A. Fazilah, M.E. Effarizah. 2015. Toxicity of Nutmeg (Myristicin): A Review. International Journal on Advance Science Engineering Information Technology. 5(3): 212215.

Rodianawati, I. 2010. Komposisi kimia oleoresin biji pala (Myristica fragrans Houtt) yang diperoleh dengan ekstraksi langsung dan ektraksi bertahap. Prosiding SN-KPK II 2010, ISBN 979(3): 498-547.

Sofyana, M., D. Supardan, Zuhra, C.A. Maulida, U. Haura. 2013. Ultrasound Assisted Extraction of Oleoresin From Nutmeg (Myristica fragrans Houtt). International Journal on Advanced Science Engineering Information Technology. 3(4):18-21.

Supardan, M.D., T.M. Asnawi, Y. Putri, S. Wahyuni. 2011. Metode Ekstraksi Pelarut Berbantuan Ultrasonik untuk Recovery Minyak dari Limbah Cair Pabrik Kelapa Sawit. Agritech. 31(4):368373.

Uju, P., S.K. Dewi, J. Santoso, I. Setyaningsih, S.D. Hardingtyas and Yopi . 2019. Extraction of Phycoerythrin From Kappaphycus Alvarezii Seaweed Using Ultrasonication. IOP Conf. Ser.: Earth Environ. Sci. 414012028.

Vinatoru, M. 2001. An Overview of The Ultrasonically Assisted Extraction of Bioactive Principles From Herbs. Ultrason Sonochem. 8:303-313.

Xia, T., S. Shi, X. Wan. 2006. Impact of UltrasonicAssisted Extraction on The Chemical and Sensory Quality of Tea Infusion. J Food Eng. 74:557-560. 
Halaman ini sengaja dikosongkan 